\title{
Age and body condition score and diets of grazing goats
}

\author{
MigUel MELlado, ALVARO RODRÍGUEZ, ABUNDIO OLVERA, JOSE A. VILlARREAL, AND RAMIRO \\ LOPEZ
}

Authors are Professor of Reproductive physiology, Professor of Range Management, Graduate Student, Professor of Botany, and Professor of Animal nutrition, Department of Nutrition and Feeds, Universidad Autonoma Agraria Antonio Narro, Saltillo, Mexico.

\section{Abstract}

Diet selection by juvenile and adult non-pregnant, non-lactating goats and the diets of adult non-productive goats with low $(\leq 1.5$; grading scale $0-5$ ) and moderate $(\geq 2.5)$ body condition score (BCS) are described by microhistological analysis of fecal samples for a Chihuahuan desert vegetation in northern Mexico. In the rainy season, adult goats utilized more $(P<0.10)$ shrubs than juvenile goats (70.4 vs $\mathbf{5 8 . 6 \% )}$, but, in the dry season, the diet of both groups contained equal amounts of shrubs. The proportion of forbs and grasses in the goats' diet also tended to vary $(\mathrm{P}<0.10)$ between age groups in the rainy season. Juvenile goats generally had lower consumption of plants with spines than adult goats. Goats with low BCS selected more $(\mathbf{P}<\mathbf{0 . 1 0})$ shrubs than goats with moderate $\mathrm{BCS}$ in the rainy season. Forbs were eaten in larger amounts by does with moderate BCS (38\% of the diet) during the rainy season compared to goats with low BCS $(30.9 \%)$. Regardless of age and body reserves, grasses formed less than $5 \%$ of goat diets in both seasons. Mean similarity index for juvenile and adult goats was $\mathbf{7 5}$, while mean similarity index for goats with low and moderate BCS was 78. For all classes of goats, Larrea tridentata (DC.) Cov., the dominating species in the plant community, was the only plant selected at proportions below those found in ground cover in the rainy season. These data indicate that, during the rainy season, juvenile goats mixed their diets to achieve more even use of forages than adult goats. These results also indicate that high utilization of shrubs, including resinous and fibrous forages, appeared to be an adaptive foraging strategy of goats with low fat reserves, when forage was readily available.

Key Words: Chihuahuan desert, botanical composition, range, preference, foraging

An understanding of the foraging strategy of goats in response to differences in internal state and body energy reserves is essential to the development of sustainable grazing systems. The effect of age on foraging behavior has received little attention in farm animals. Previous research with small ruminants has shown that age influences plant selection under range conditions (Richman and Johnson 1995), but not on irrigated pastures (DeRosa et al. 1997). In another study, sheep of different age classes utilized feed blocks to markedly different extents (Lawrence and WoodGush 1998). A number of researchers have reported differences in diet selection between old and young cattle (Ferrer Cazcarra and Petit 1995, Grings et al. 2001).

Manuscript accepted 21 Feb. 04.

\section{Resumen}

En este estudio se describe la selección de la dieta de cabras en crecimiento en comparación con cabras adultas no lactantes y no gestantes, $y$ las dietas de cabras adultas no productivas con baja ( $\leq 1.5$ ) o moderada ( $\geq 2.5$ ) condición corporal (CC). El estudio se llevó a cabo en el noreste de México, en un tipo de vegetación del Desierto Chihuahuense. Los análisis microhistológicos de las heces mostraron que durante el periodo de lluvia, las cabras adultas tendieron a utilizar más $(\mathbf{P}<0.10)$ las arbustivas que las cabras jóvenes $(70.4$ vs $\mathbf{5 8 . 6 \%}$ ), pero en la época de lluvias, la dieta de ambos categorías de cabras presentaron igual proporción de arbustivas. La proporción de herbáceas y pastos en la dieta de las cabras también se vio influenciada $(\mathbf{P}<0.10)$ por la edad en la época de lluvia. En general las cabras jóvenes mostraron un menor consumo de plantas con espinas, en comparación con las cabras adultas. Las cabras con pobre $\mathbf{C C}$ tendieron a seleccionar más $(P<\mathbf{0 . 1 0})$ arbustivas que las cabras con moderada CC. La utilización de herbáceas por las cabras de moderada CC fue mayor ( $38 \%$ de la dieta) durante la época de sequía en comparación con las cabras de pobre CC (30.9\%). Independientemente de la edad $\mathbf{y}$ reservas corporales de las cabras, los pastos constituyeron menos del $5 \%$ de la dieta en ambas estaciones de muestreo. El promedio del índice de similaridad de las dietas de cabras jóvenes y adultas fue de 75 . El promedio de este índice para las dietas de las cabras con pobre o moderada CC fue de 78. Para todas las cabras, Larrea tridentata (DC.) Cov., la especie más abundante en el agostadero, fue la única planta que fue seleccionada en una proporción inferior a su cobertura del agostadero. Estos datos mostraron que las cabras jóvenes seleccionaron una mayor proporción de especies con alto valor nutritivo en comparación con las cabras adultas, aparentemente con la estrategia de optimizar la ingestión de nutrientes durante la época de humedad, y de explorar su ambiente. Estos datos indican también que una alta utilización de arbustivas, incluyendo especies poco preferidas, parece ser la estrategia alimenticia de cabras con reducidas reservas de grasa corporal, durante la época de mayor disponibilidad de forraje

Regarding body reserves, Murden and Risenhoover (1993) contend that animals in a high nutritional state will often be more selective and choose diets different than animals in poor nutritional status. To our knowledge, no data on age-specific differences in goat diets on the Chihuahuan desert vegetation exists. The effect of body reserves on forage selectivity in grazing goats is also unknown. Our goal was to investigate the age and body condition effects on botanical composition and diet selectivity of grazing goats. 


\section{Materials and Methods}

\section{Study Site Description}

The study was conducted in a rural area in northeast Mexico $\left(101^{\circ} 20^{\prime} \mathrm{W}, 25^{\circ} 30^{\prime}\right.$ N). Annual precipitation averaged $32.2 \mathrm{~cm}$ from 1990-1999, with $75 \%$ falling from June to October. July is normally the wettest month with rainfall averaging 5.8 $\mathrm{cm}$. Average maximum daily temperatures range from $28^{\circ} \mathrm{C}$ in January to $37.2^{\circ} \mathrm{C}$ in July. Average minimum daily temperatures range from $-7^{\circ} \mathrm{C}$ in January to $12.3^{\circ}$ $\mathrm{C}$ in July. Elevation varies from 1600 to $1800 \mathrm{~m}$ with level or gently rolling hills. Brown to pale brown loams, mostly calcareous, are the main soil type.

The most abundant shrub species was creosotebush (Larrea tridentata (DC.) Cov.). Other less abundant shrubs were lechuguilla (Agave lechuguilla Torr.), pricklypear (Opuntia rastrera Weber.), huizache (Acacia farnesiana (L.) Willd.) and tarbush (Flourensia cernua DC.). The main grasses were sideoats grama (Bouteloua curtipendula (Michx.) Torr.) and Arizona three-awn (Aristida arizonica Vasey). The most common forb species were globe-mallow (Sphaeralcea angustifolia (Cav.) D. Don.) and silver-leaf nightshade (Solanum elaeagnifolium Cav.). Historically, this pasture has been heavily stocked (approximately 1.5 ha per goat) and continuously grazed exclusively by large herds of goats.

\section{Animals and Management}

A commercial flock of goats $(n=250)$ of undefined genotype (mixture of Granadina, dairy and criollo goats) were utilized in this study. Animals were penned near the household at night without access to feed and water. No salt or food supplements were provided to the goats throughout the year. Goats were not subjected to an anthelmintic drenching program. Fortyeight goats: 18 adults and 6 juveniles for the rainy period, and the same number of animals for the dry period (individuals were not the same between periods) were selected from this flock.

To evaluate the effect of animal age, 6 juvenile goats approximately 2.5 months of age, with a mean live weight of 15.3 (SD $2.1) \mathrm{kg}$ for the rainy season and 13.7 (SD 1.9) $\mathrm{kg}$ for the dry season, and 6 adult nonproductive does with an average live weight of 39.4 (SD 3.3) for the rainy season and 37.1 (SD 3.8) kg for the dry season, of similar backgrounds were used to study the effect of age on food preferences.

Twelve does were used to evaluate the effects of body condition on diet selection.
Six of them were adult non-lactating does (more than 3 parturitions) in a poor body condition score (BCS) $(\leq 1.5$; grading scale 0-5; Santucci and Maestrini 1985), and 6 were multiparous goats with moderate BCS $(\geq 2.5)$. The BCS were assigned by 1 trained individual, who determined the degree of fatness based on tactile appraisal of fat in the sternum and lumbar vertebrae. The BCS were achieved naturally, without food supplementation to adjust it.

Adult does were not pregnant, growing or lactating, and they moved fairly independently in controlled areas and the time spent in grazing activity was the same. It was assumed that tactical decisions about what diet to select was driven by the search of an adequate level of nutrients to meet the maintenance demands (Kyriazakis et al. 1999).

Goats grazed in an arid rangeland driven by a herdsmen 8 hours daily (from 1000 to 1800 hours). Grazing constraints related to diet selection were considered negligible because goats were taken to different grazing sites every day, and animals walked long distances daily (about $3 \mathrm{~km}$ from the pen). These grazing patterns allowed free choice among existing plant species. Stocking rate was 1.5 ha per goat, which was above the carrying capacity of this rangeland.

\section{Diet Analysis}

Fecal samples (approximately 10 pellets per animal) were collected from the rectum of goats in 2 seasons. During each season, fecal samples were collected from each goat on 5 consecutive days. Different goats were used in each season. The samples were dried at $50^{\circ} \mathrm{C}$ in an oven for 72 hours and then ground in a Willey mill to pass a $1-\mathrm{mm}$ mesh screen. The samples were bulked, thoroughly mixed, and a subsample taken from the mixture. Botanical composition of goat diets was determined using the microhistological technique described by Sparks and Malechek (1968). Five slides from each sample were analyzed with a compound, phase-contrast microscope until 100 fragments were identified. Goat preferences for the most important forage species were evaluated with a relative preference index (Van Dyne and Heady 1965):

$\begin{gathered}\text { Relative } \\ \text { preference } \\ \text { index }\end{gathered}=\frac{(\% \text { forage species in diet })}{\begin{array}{c}\text { (\% forage species in } \\ \text { pasture })\end{array}}$

Index values of 1.0 indicated nonselective use of the species; values $>1$ or $<1$ indicated grazing selectivity for or against a par- ticular species, respectively. Similarity of diets was calculated using Kulczynski's similarity index (Oosting 1956):

$$
I=\frac{(2 w \times 100)}{(a+b)}
$$

where $\mathrm{SI}=$ similarity index, $\mathbf{w}$ is the smaller percentage of 1 plant species in the diet of 2 different animal species, and $(a+b)$ is the sum of 2 percentages of utilization of 1 plant species.

\section{Vegetation analysis}

Vegetation cover in the pasture was determined simultaneously with each 5 days fecal collection periods, at the end of the rainy season (October 2001) and dry season (February 2002). Percent canopy cover was measured with five, $500-\mathrm{m}$ permanent transects evenly distributed over the study area. Plants that were located on the plane horizontally above the transect line were measured. The intercept of each plant by species was summed and divided by the total length of each transect to obtain the percent cover (Canfield 1942).

\section{Statistical analysis}

Prior to statistical analysis, the numbers of epidermal fragments of each species were converted to percentages and transformed to arcsin (angular) (Steel and Torrie 1980) to normalize their distribution. The individual animal was the sampling unit $(n=6)$ for all analyses. A one way ANOVA (SAS 1990), with animal category as factor, was used to detect differences between animal groups, within seasons. It was assumed that the restriction imposed on the randomization did not affect responses. Error terms for animal categories were the variation among animals within periods. To aid in the interpretation of preference indexes, these were tested by constructing confidence intervals (CI) for each mean of Relative Preference Index, following the formula of Hobbs and Bowden (1982). Selectivity was significant when the interval did not contain the value 1.0

\section{Results}

\section{Vegetation cover}

To develop a perspective of the plant community structure, the aerial cover of plant groups in the rainy and dry periods are presented in Fig. 1. In both periods, shrubs, the most used plants by goats in this community, made up over $75 \%$ of the total ground cover, whereas grasses com- 


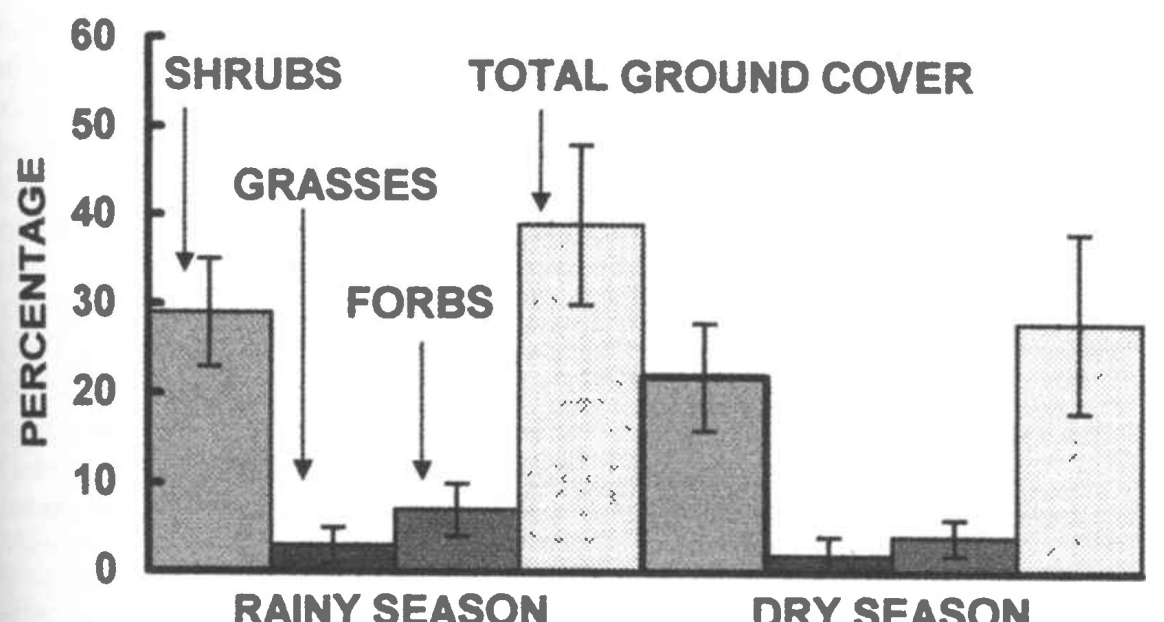

RAINY SEASON

Fig. 1. Variations in plant cover with season. Data are percentage of group of plants cover based on five, $500-\mathrm{m}$ transects spaced in the study site. Vertical bars represent standard deviations.

prised less than $7 \%$ of the total vegetation cover. The total ground cover decreased 10 percent points over the 2 periods of the trial.

\section{Effect of Age}

The contribution of shrubs to the diets of adult does was 12 percentage units greater $(P<0.10)$ than juvenile does in the rainy season (Table 1). The proportion of forbs and grasses in the goats' diet also tended to vary between age groups in the rainy seasons $(P<0.10)$. There was no difference among juvenile and adult animals in the proportion of browse, forbs and grasses in their diets in the dry season. Adult goats consumed more $(\mathrm{P}<0.05)$ Condalia warnockii than juvenile does during the rainy season, but equal proportions of this shrub occurred in the diets of both groups in the dry season. Both adult and juvenile does relied heavily on Parthenium incanum in both seasons. During the rainy season Larrea tridentata was a minor component of the adult and juvenile doe diets, but the decreased in regetation cover during the dry season encouraged adult goats to utilize this shrub in higher proportion $(\mathrm{P}<0.05)$ than juvenile goats. Adult goats consumed more $(\mathrm{P}<0.05)$ Agave lechuguilla than did juvenile does during the rainy season, and this fibrous shrub was avoided by juvenile animals during the dry season.

Prosopis glandulosa made up 7\% of the adult does' diet when conditions dried out and suitable forage declined, while this shrub was a negligible component of the diet of juvenile does in this season. During the rainy season, percentage of thorny succulent shrubs (Opuntias) was 3-fold higher in adult does diet than juvenile does' diet. Likewise, as vegetation cover declined, adult goats consumed twice as many suc-

\section{DRY SEASON}

culent thorny species as juvenile does. Grasses were minor components in adult goats diets in the rainy season, while diets of juvenile does contained up to 5\% grasses in both seasons. Juvenile does relied on sideoats grama (Bouteloua curtipendula)

as their primary source of grass in the dry season; whereas, adult does consumed different grass species in relatively equal proportions in this season.

Dietary preferences of adult and juvenile does for various plants are shown in Table 2. Overall, diet composition of both groups of goats was not related to vegetation cover. Adult goats showed preference for Agave lechuguilla and Opuntia leptocaulis in the rainy season and Opuntia leptocaulis and Opuntia rastrera in the dry period, whereas juvenile goats avoided them. The only plant species that was avoided by both groups of goats in the rainy season was Larrea tridentata. Dietary overlap between age groups was high in the rainy season (similarity index $=73$ ) and increased during drought conditions (similarity index $=80$ ).

\section{Effect of Body Condition Score}

Shrubs made up the majority of goats' diets throughout the study regardless of BCS (Table 3). During the rainy season, goats with low BCS tended to select more

Table 1. Diet composition of diets of juvenile and adult does in a Chihuahuan desert rangeland in 2 seasons. Values are percent occurrence of main species (mean \pm SD) identified in feces.

\begin{tabular}{|c|c|c|c|c|}
\hline \multirow[t]{2}{*}{ Species } & \multicolumn{2}{|c|}{ Rainy season } & \multicolumn{2}{|c|}{ Dry season } \\
\hline & Adults & Juvenile & Adults & Juvenile \\
\hline & - & - & & \\
\hline Acacia berlandieri Benth. & $3.1 \pm 2.3$ & $1.3 \pm 1.4$ & - & $1.3 \pm 1.0$ \\
\hline Acacia farnesiana (L.) Willd. & $4.4 \pm 3.0$ & $5.7 \pm 2.6$ & $3.5 \pm 3.2^{\alpha}$ & $7.0 \pm 2.7^{\beta}$ \\
\hline Agave lechuguilla Torr. & $6.2 \pm 3.2^{\mathrm{a}}$ & $2.6 \pm 1.7^{b}$ & $0.5 \pm 0.4$ & - \\
\hline Agave striata Zucc. & $1.0 \pm 1.0^{\alpha}$ & $3.7 \pm 2.7^{\beta}$ & - & $2.8 \pm 2.5$ \\
\hline Buddleja scordioides HBK. & $1.0 \pm 1.1$ & - & $4.8 \pm 2.5$ & $7.6 \pm 4.4$ \\
\hline Condalia warnockii M.C. Johnst. & $4.2 \pm 1.7^{\mathrm{a}}$ & $0.4 \pm 0.9^{b}$ & $11.2 \pm 3.7$ & $11.5 \pm 1.9$ \\
\hline Cowania plicata D. Don & $7.7 \pm 3.6$ & $6.2 \pm 3.1$ & $5.7 \pm 3.8$ & $4.3 \pm 5.1$ \\
\hline Dasylirion palmeri Trel & $3.9 \pm 1.1$ & $3.1 \pm 3.0$ & $1.7 \pm 1.7$ & - \\
\hline Flourensia cernua DC. & $3.5 \pm 2.2$ & $1.9 \pm 1.9$ & - & - \\
\hline Larrea tridentatea (DC.) Cov. & $3.8 \pm 1.1$ & $4.3 \pm 1.6$ & $9.2 \pm 3.0^{\mathrm{a}}$ & $4.5 \pm 2.9^{b}$ \\
\hline Opuntia imbricata (Haw.) DC. & $2.8 \pm 0.7$ & - & $4.4 \pm 4.5$ & $4.8 \pm 4.7$ \\
\hline Opuntia leptocaulis (DC.) & $0.9 \pm 1.0$ & $0.5 \pm 0.5$ & $4.5 \pm 3.7_{-}$ & $0.5 \pm 0.8^{\beta}$ \\
\hline Opuntia rastrera Weber & $2.1 \pm 1.8$ & $1.6 \pm 1.5$ & $4.1 \pm 3.2^{\mathrm{a}}$ & $0.1 \pm 0.1^{b}$ \\
\hline Parthenium incanum $\mathrm{HBK}$. & $15.1 \pm 4.8$ & $17.0 \pm 3.4$ & $17.7 \pm 4.0$ & $15.1 \pm 5.6$ \\
\hline Pinus cembroides Zucc. & - & - & $1.4 \pm 1.9^{\mathrm{A}}$ & $6.5 \pm 5.2^{B}$ \\
\hline Prosopis glandulosa Torr. & $1.0 \pm 0.9^{A}$ & $4.0 \pm 1.6^{B}$ & $7.1 \pm 4.5^{\mathrm{a}}$ & $1.3 \pm 1.7^{\mathrm{b}}$ \\
\hline Other shrubs & 9.7 & 6.3 & 8.1 & 15.4 \\
\hline Total shrubs & $70.4 \pm 37.3$ & $58.6 \pm 32.5$ & $83.9 \pm 52.5$ & $82.9 \pm 59.8$ \\
\hline Croton dioicus Cav. & $11.2 \pm 5.5$ & $7.5 \pm 1.3$ & $7.9 \pm 4.7$ & $4.5 \pm 3.1$ \\
\hline Sida abutifolia Mill. & $2.6 \pm 1.7$ & $3.6 \pm 2.3$ & $0.3 \pm 0.4$ & $1.4 \pm 1.6$ \\
\hline Solanum elaeagnifolium Cav. & $9.2 \pm 4.8^{\mathrm{a}}$ & $14.3 \pm 3.1^{b}$ & - & - \\
\hline Sphaeralcea angustifolia (Cav.) G. Don & $3.9 \pm 2.3^{\mathrm{A}}$ & $11.6 \pm 4.4^{B}$ & $2.3 \pm 2.1$ & $2.3 \pm 2.0$ \\
\hline Tiquilia canescens (DC.) A. Rich. & - & - & $2.1 \pm 2.3$ & $3.6 \pm 3.7$ \\
\hline Other forbs & 1.6 & 0.3 & 0.2 & 0.4 \\
\hline Total forbs & $28.5 \pm 15.6^{\alpha}$ & $37.3 \pm 11.6^{\beta}$ & $12.8 \pm 9.8$ & $12.2 \pm 10.6$ \\
\hline Bouteloua curtipendula (Mich.) Torr. & - & $1.0 \pm 1.2$ & $1.4 \pm 1.7$ & $3.5 \pm 2.8$ \\
\hline Other grasses & 1.1 & 3.1 & 1.9 & 1.4 \\
\hline Total grasses & $1.1 \pm 1.0^{\alpha}$ & $4.1 \pm 3.7^{\beta}$ & $3.3 \pm 3.8$ & $4.9 \pm 4.1$ \\
\hline
\end{tabular}

Empty cells indicate that plants were not utilized by goats.

Values in the same line within season with different superscript differ $\left({ }^{\alpha \beta} \mathrm{P}<0.10 ;{ }^{\mathrm{a} . \mathrm{b}} \mathrm{P}<0.05 ;{ }^{\mathrm{A} . \mathrm{B}} \mathrm{P}<0.01\right)$. 
Table 2. Mean selectivity index values and $95 \%$ CI of main plant species in diets of adult and juvenile does on a Chihuahuan desert rangeland in northern Mexico in 2 collection seasons.

\begin{tabular}{|c|c|c|c|c|}
\hline \multirow[b]{2}{*}{ Species } & \multicolumn{2}{|c|}{ Rainy season } & \multicolumn{2}{|c|}{ Dry season } \\
\hline & Adults & Juvenile & Adults & Juvenile \\
\hline & \multicolumn{4}{|c|}{ - } \\
\hline Acacia berlandieri Benth. & $2.1(0.1-4.1)$ & $0.9(0.0-1.8)$ & - & $1.1(0.2-1.9)$ \\
\hline Acacia farnesiana (L.) Willd. & $3.4(2.0-4.8)$ & $4.4(2.1-6.7)$ & $3.9(2.3-5.5)$ & $7.8(4.1-11.5)$ \\
\hline Agave lechuguilla Torr. & $2.6(1.7-3.5)$ & $0.7(0.5-0.9)$ & $0.5(0.2-0.8)$ & - \\
\hline Agave striata Zucc. & $0.7(0.5-0.9)$ & $2.8(1.9-3.7)$ & - & $2.8(2.0-3.6)$ \\
\hline Buddleja scordioides HBK. & $0.6(0.2-1.0)$ & - & $3.4(2.5-4.3)$ & $5.4(2.7-8.1)$ \\
\hline Condalia warnockii M.C. Johnst. & $2.0(1.1-2.9)$ & $0.2(0.0-0.4)$ & $6.6(4.5-9.1)$ & $6.8(4.7-8.9)$ \\
\hline Cowania plicata D. Don & $4.1(1.4-6.8)$ & $3.3(2.3-4.3)$ & $4.4(2.6-6.2)$ & $3.3(1.3-5.3)$ \\
\hline Dasylirion palmeri Trel & $3.5(2.2-4.8)$ & $2.8(1.6-4.0)$ & $0.9(0.2-1.6)$ & - \\
\hline Flourensia cernua DC. & $2.7(1.2-4.2)$ & $1.5(0.8-2.2)$ & - & - \\
\hline Larrea tridentatea (DC.) Cov. & $0.4(0.1-0.7)$ & $0.5(0.3-0.8)$ & $1.5(0.6-2.4)$ & $0.7(0.2-1.2)$ \\
\hline Opuntia imbricata (Haw.) DC. & $3.5(2.1-4.9)$ & - & $6.3(3.8-8.8)$ & $5.4(3.0-7.8)$ \\
\hline Opuntia leptocaulis (DC.) & $1.8(0.7-2.9)$ & $0.5(0.2-0.8)$ & $8.0(5.3-10.7)$ & $0.7(0.5-0.9)$ \\
\hline Opuntia rastrera Weber & $3.0(2.0-4.0)$ & $2.3(1.4-3.2)$ & $6.8(4.2-9.4)$ & $0.2(0.1-0.3)$ \\
\hline Parthenium incanum HBK. & $5.0(2.5-7.5)$ & $5.7(3.0-8.4)$ & $6.3(3.6-9.0)$ & $5.4(3.0-7.8)$ \\
\hline Prosopis glandulosa Torr. & $1.4(0.0-2.8)$ & $5.6(3.6-7.6)$ & $11.1(7.6-15.3)$ & $2.1(0.8-3.4)$ \\
\hline Croton dioicus Cav. & $8.1(4.6-12.1)$ & $5.8(4.0-7.6)$ & $9.8(5.6-14.0)$ & $5.6(1.8-9.4)$ \\
\hline Sida abutifolia Mill. & $2.2(0.7-3.7)$ & $3.6(2.7-4.5)$ & $1.0(0.4-1.6)$ & $4.7(3.3-6.1)$ \\
\hline Solanum elaeagnifolium Cav. & $8.1(4.6-11.6)$ & $11.1(7.9-14.3)$ & - & - \\
\hline $\begin{array}{l}\text { Sphaeralcea angustifolia (Cav.) } \\
\text { G. Don }\end{array}$ & $3.0(1.5-4.5)$ & $6.3(3.0-9.6)$ & $2.6(1.2-4.0)$ & $2.6(1.8-3.4)$ \\
\hline Tiquilia canescens (DC.) A. Rich. & - & - & $7.0(5.18 .9)$ & $10(6.3-14.1)$ \\
\hline Bouteloua curtipendula (Mich.) Torr. & $\longrightarrow$ & $1.7(0.8-2.6)$ & $2.8(1.9-3.7)$ & $7.0(4.5-9.5)$ \\
\hline
\end{tabular}

Empty cells indicate that plants were not utilized by goats.

Indexes whose lower limit of the $95 \% \mathrm{Cl}$ exceeds 1.0 indicate preference. Indexes whose upper limit of the $95 \% \mathrm{Cl}$ is less than 1.0 indicate avoidance, and indexes whose $95 \% \mathrm{Cl}$ include 1.0 indicate random selection.

$(\mathrm{P}<0.10)$ browse than goats with moderate BCS, but both groups of goats consumed similar amounts of browse in the dry season. Parthenium incanun was the most consumed shrub by goats with low and moderate BCS goats in this study in both seasons. During the rainy season goats with moderate BCS utilized more ( $\mathrm{P}$ $<0.05)$ Atriplex canescens than goats with low BCS. Buddleja scordioides was another tender-leaved shrub consumed in greater $(\mathrm{P}<0.10)$ proportion by goats with moderate $\mathrm{BCS}$ than goats with low BCS during the dry season. Goats with low BCS consumed more $(\mathrm{P}<0.05)$ Agave lechuguilla than goats with moderate $\mathrm{BCS}$ during the rainy season.

Goats with moderate BCS consumed more $(P<0.10)$ forbs than goats with low BCS did in the rainy season. Sphaeralcea angustifolia was the most selected forb by goats with moderate BCS in the rainy season, while in the dry period, goats with moderate BCS consumed considerable amounts of Croton dioicus. During the rainy season, goats with low BCS utilized trace amounts of grasses, and as the quality and quantity of forage decreased in the dry season, these goats made a negligible use of grass.

Overall, there were similarities among preferences for dietary components in both groups of goats (Table 4). Of note, for the rainy season, goats with low BCS showed preference for Agave lechuguilla, whereas goats with moderate BCS avoided it. Both, goats with low and moderate BCS rejected Larrea tridentata in the rainy season. Goats with moderate BCS showed random selection for Condalia warnockii during the rainy season, whereas thin goats avoided this shrub. Overlap in forage species used by the 2 classes of goats was relatively high in both collection seasons, as indicated by the similarity indexes $(74$ and 82 for the rainy and dry seasen, respectively).

\section{Discussion}

\section{Age Effect}

The general feature of adult goat diets during the rainy season was the high levels of shrub intake and the low preference for grasses. This foraging strategy seems to be due to the larger body and bite size and muzzle width in older goats, which apparently allowed older goats to have greater access to the most abundant forage: woody plants. These results fit with earlier

Table 3. Diet composition of adult goats in different body conditions in a Chihuahuan desert rangeland of northern Mexico. Diets are percent occurrence (mean \pm S.D.) of main species in the feces.

\begin{tabular}{|c|c|c|c|c|}
\hline \multirow[t]{2}{*}{ Species } & \multicolumn{2}{|c|}{ Rainy season } & \multicolumn{2}{|c|}{ Dry season } \\
\hline & $\mathrm{BCS} \leq 1.5$ & $\overline{B C S} \geq 2.5$ & $\mathrm{BCS} \leq 1.5$ & $\mathrm{BCS} \geq 2.5$ \\
\hline & 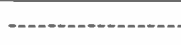 & - & & - \\
\hline Acacia berlandieri Benth. & $3.1 \pm 2.2^{\alpha}$ & $0.8 \pm 0.8^{\beta}$ & - & - \\
\hline Acacia farnesiana (L.) Willd. & $4.4 \pm 3.0$ & $6.2 \pm 5.9$ & $4.4 \pm 2.6$ & $6.7 \pm 4.6$ \\
\hline Agave lechuguilla Torr. & $6.2 \pm 4.3^{\mathrm{a}}$ & $0.7 \pm 0.7^{b}$ & $0.5 \pm 0.9$ & $2.2 \pm 2.9$ \\
\hline Atriplex canescens (Pursh.) Nutt. & $1.4 \pm 1.4^{\mathrm{a}}$ & $5.2 \pm 3.7^{b}$ & $2.2 \pm 2.9$ & 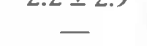 \\
\hline Buddleja scordioides HBK. & - & $1.0 \pm 1.8$ & $3.2 \pm 1.8$ & $6.8 \pm 4.0_{-}$ \\
\hline Condalia warnockii M.C. Johnst. & $1.2 \pm 1.4$ & $1.6 \pm 1.1$ & $10.9 \pm 4.1$ & $10.0 \pm 1.3$ \\
\hline Cowania plicata D. Don & $7.7 \pm 3.7$ & $9.8 \pm 3.8$ & $5.7 \pm 3.0$ & $4.7 \pm 3.9$ \\
\hline Dasylirion palmeri Trel & $3.9 \pm 1.5^{\circ}$ & $3.3 \pm 1.6$ & $1.8 \pm 1.7$ & $3.1 \pm 2.8$ \\
\hline Flourensia cernua DC. & $3.5 \pm 3.0$ & - & $2.0 \pm 2.7$ & $0.3 \pm 0.6$ \\
\hline Larrea tridentatea (DC.) Cov. & $3.8 \pm 1.9$ & $4.1 \pm 1.6$ & $7.4 \pm 2.7$ & $9.2 \pm 1.4$ \\
\hline Opuntia leuvotricha DC. & 3.0 & - & $4.1 \pm 4.3$ & $7.3 \pm 3.4$ \\
\hline Opuntia rastrera Weber & $2.1 \pm 1.9$ & $2.4 \pm 1.4$ & $4.1 \pm 3.2$ & $2.1 \pm 3.3$ \\
\hline Parthenium incanum HBK. & $15.1 \pm 4.9$ & $13.8 \pm 8.0$ & $17.4 \pm 7.0$ & $17.0 \pm 4.1$ \\
\hline Prosopis glandulosa Torr. & $1.0 \pm 1.0$ & $2.3 \pm 1.5$ & $5.2 \pm 3.5$ & $6.3 \pm 2.3$ \\
\hline Other shrubs & 14.7 & 6.5 & 16.4 & 7.9 \\
\hline Total shrubs & $68.1 \pm 42.3$ & $57.7 \pm 33.3$ & $85.3 \pm 55.8$ & $83.6 \pm 45.4$ \\
\hline Croton dioicus Cav. & $11.2 \pm 5.5$ & $7.5 \pm 5.8$ & $5.8 \pm 3.7$ & $11.6 \pm 5.9$ \\
\hline Sida abutifolia Mill. & $2.6 \pm 2.4$ & $4.1 \pm 3.9$ & $0.3 \pm 0.7$ & - \\
\hline Solanum elaeagnifolium Cav. & $9.1 \pm 3.1$ & $9.5 \pm 2.8$ & - & - \\
\hline Sphaeralcea angustifolia (Cav.) G. Don & $3.9 \pm 3.6^{\mathrm{A}}$ & $12.2 \pm 1.8^{B}$ & $2.3 \pm 2.0$ & - \\
\hline Tiquilia canescens (DC.) A. Rich. & $1.4 \pm 0.9$ & $4.1 \pm 2.7$ & $2.1 \pm 2.4$ & $2.1 \pm 2.6$ \\
\hline Other forbs & 2.7 & 0.6 & 0.9 & 0.6 \\
\hline Total forbs & $30.9 \pm 7.9$ & $38.0 \pm 9.7$ & $11.4 \pm 10.9$ & $14.3 \pm 9.6$ \\
\hline Bouteloua curtipendula (Mich.) Torr. & - & $1.0 \pm 1.3$ & $2.5 \pm 3.1$ & $1.7 \pm 2.0$ \\
\hline Other grasses & 1.0 & 3.3 & 0.8 & 0.4 \\
\hline Total grasses & $1.0 \pm 1.4$ & $4.3 \pm 4.7$ & $3.3 \pm 4.3$ & $2.1 \pm 2.7$ \\
\hline
\end{tabular}

Empty cells indicate that plants were not utilized by goats.

Values in the same line within season with different superscript differ $\left({ }^{\alpha \beta} \mathrm{P}<0.10 ;{ }^{a, b} \mathrm{P}<0.05\right.$; $\left.{ }^{A . \mathrm{B}} \mathrm{P}<0.01\right)$. 
Table 4. Mean selectivity index values and $95 \%$ CI of main plant species in diets of does with low or moderate body condition score, on a Chihuahuan desert rangeland in northern Mexico in 2 collection seasons.

\begin{tabular}{|c|c|c|c|c|}
\hline \multirow[t]{2}{*}{ Species } & \multicolumn{2}{|c|}{ Rainy season } & \multicolumn{2}{|c|}{ Dry season } \\
\hline & $\mathrm{BCS} \leq 1.5$ & $\mathrm{BCS} \geq 2.5$ & $\mathrm{BCS} \leq 1.5$ & $\mathrm{BCS} \geq 2.5$ \\
\hline & & & & 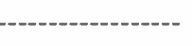 \\
\hline Acacia berlandieri Benth. & $2.1(1.6-2.6)$ & $0.5(0.3-0.7)$ & - & - \\
\hline Acacia farnesiana (L.) Willd. & $3.4(1.8-5.4)$ & $4.8(3.0-6.6)$ & $4.9(3.1-6.7)$ & $7.4(5.0-9.8)$ \\
\hline Agave lechuguilla Torr. & $2.6(1.7-3.5)$ & $0.3(0.1-0.5)$ & $0.5(0.2-0.8)$ & $2.2(1.1-3.3)$ \\
\hline Atriplex canescens (Pursh.) Nutt. & $1.2(0.8-1.6)$ & $4.3(3.0-5.6)$ & $2.4(2.0-2.8)$ & - \\
\hline Buddleja scordioides HBK. & - & $0.6(0.3-0.9)$ & $2.3(1.5-3.1)$ & $4.9(3.1-6.7)$ \\
\hline Condalia warnockii M.C. Johnst. & $0.6(0.3-0.9)$ & $0.8(0.5-1.1)$ & $6.4(4.4-8.4)$ & $5.9(3.6-8.2)$ \\
\hline Cowania plicata D. Don & $4.0(2.7-5.3)$ & $5.2(3.5-6.9)$ & $4.4(3.1-5.7)$ & $3.6(1.9-5.3)$ \\
\hline Dasylirion palmeri Trel & $3.5(2.0-5.0)$ & $3.0(1.6-4.4)$ & $2.3(1.3-3.3)$ & $3.9(2.1-5.7)$ \\
\hline Flourensia cernua DC. & $2.7(1.9-3.5)$ & - & $2.5(1.7-3.3)$ & $0.4(0.1-0.7)$ \\
\hline Larrea tridentatea (DC.) Cov. & $0.4(0.2-0.6)$ & $0.5(0.2-0.8)$ & $1.2(0.5-1.9)$ & $1.5(0.7-2.3)$ \\
\hline Opuntia leuvotricha DC. & - & - & $4.1(2.8-5.4)$ & $7.3(4.8-9.8)$ \\
\hline Opuntia rastrera Weber & $3.0(1.8-4.2)$ & $3.4(2.6-4.2)$ & $6.8(5.0-8.6)$ & $3.5(1.9-5.1)$ \\
\hline Parthenium incanum $\mathrm{HBK}$. & $5.0(3.5-6.5)$ & $4.6(2.7-6.5)$ & $6.2(3.9-8.5)$ & $6.1(4.2-8.0)$ \\
\hline Prosopis glandulosa Torr. & $1.4(0.4-2.4)$ & $3.3(2.2-4.4)$ & $8.7(6.6-10.8)$ & $8.5(6.0-11.0$ \\
\hline Croton dioicus Cav. & $8.6(6.4-10.8)$ & $5.8(3.9-7.7)$ & $7.3(5.5-9.1)$ & $11.5(8.6-14.4)$ \\
\hline Sida abutifolia Mill. & $2.6(2.0-3.2)$ & $4.1(2.6-5.6)$ & $1.0(0.6-1.4)$ & - \\
\hline Solanum elaeagnifolium Cav. & $11.4(8.3-14.5)$ & $11.9(8.1-15.7)$ & - & - \\
\hline $\begin{array}{l}\text { Sphaeralcea angustifolia (Cav.) } \\
\text { G. Don }\end{array}$ & $3.5(2.4-4.6)$ & $8.3(5.5-11.1)$ & $2.6(1.8-3.4)$ & - \\
\hline Tiquilia canescens (DC.) A. Rich. & $2.3(1.4-3.2)$ & $6.8(4.8-8.8)$ & $7.0(3.9-10.1)$ & $7.0(4.1-9.9)$ \\
\hline Bouteloua curtipendula (Mich.) Torr. & - & $1.7(0.9-2.5)$ & $5.0(3.2-6.8)$ & $3.4(0.9-5.9)$ \\
\hline
\end{tabular}

Empty cells indicate that plants were not utilized by goats.

Indexes whose lower limit of the $95 \% \mathrm{Cl}$ exceeds 1.0 indicate preference. Indexes whose upper limit of the $95 \% \mathrm{Cl}$ is less than 1.0 indicate avoidance, and indexes whose $95 \% \mathrm{Cl}$ include 1.0 indicate random selection.

observations where, in environments with abundant browse, large body size of herbivores is advantageous in gaining access to food (Du Toit 1990, Bugalho et al. 2001). Other authors have proposed that allometric differences between body size and bite size, incisor breath and muzzle width lead to different intake abilities between animals of different size in artiodactyls (Illius and Gordon 1987, Pérez-Barbería and Gordon 1998).

In the same season, juvenile does relied heavily on shrubs, although forbs made up more than one third of their diet. An important dietary overlap was observed with Parthenium incanun, which was the predominant forage in adult and juvenile goat diets in both seasons. The high utilization of this species by goats is consistent with previous research in the same type of vegetation (Mellado et al. 1991, 2003).

Juvenile goats made no use of Agave lechuguilla, while adult goats made a moderate use of this fibrous shrub during the rainy season. Juvenile goats may not have the grazing experience with this species to have developed the skills to use this Agavaceae. Goats only eat the less fibrous tissue of this plant, located under the blades' terminal spine. Goats must learn to remove the stout, sharp terminal spine of the blades of this plant in order to pluck the less fibrous fraction of this plant. Adult goats also showed a higher uti- lization of plants with spines during both seasons, than juvenile goats. This suggests that juvenile goats were more sensitive to the physical anti-quality attributes of plants than adult goats, while adult goats seem to have higher skills to handle thorns and pluck tissue of succulent plants. Therefore, thorns seem to be less effective at deterring grazing as goats become more experienced at handling spine bearingplants. Aversion acquired in young animals is less resistant to extinction than those in older animals (Ralphs and Provenza 1999), so, as goats grew older, possibly social facilitation extinguished aversion of goats to cactuses.

Another shrub of singular importance during the dry season was Acacia farnesiana, which was utilized in greater proportions by juvenile compared to adult goats. The greater use of this legume shrub by juvenile goats may be explained by its high nutrient content and palatability, and its low levels of tannins (Ramirez et al. 1999). As vegetation cover decreased due to climate conditions, adult and juvenile goats increased the amounts of browse in their diet, and compensated for the increase of brush utilization by reducing their consumption of forbs. Of note, Larrea tridentata alone, a resinous shrub with a high and diverse concentrations of allelochemicals (Hyder et al. 2002), accounted for $9 \%$ of the total forage ingested by adult goats during the dry season. Also during the dry season, Prosopis glandulosa was significantly more important in adult diets than juvenile goat diets. Consumption of this leguminous tree by adult goats was over twice that reported for goats diets in the Chihuahuan desert rangeland (Mellado et al. 1991, Lopez-Trujillo and GarcíaElizondo 1995). Levels of Prosopis glandulosa ingestion similar to those observed in the present study have caused toxicity in goats (Mellado et al. 2003), therefore, perhaps adult goats developed adaptive mechanisms to lessen the impacts of the allelochemicals of this leguminous tree (Baptista and Launchbaugh 2001).

Juvenile goats consumed more forbs than adult goats during the rainy season, with Solanum elaeagnifolium being the most abundant. This forb contains high levels of alkaloids (Pfister et al. 2001). Nonetheless, the anti-quality factors of these forage plants did not deter juvenile goats. Only 2 forbs contributed substantially to the juvenile goats diet: Solanum elaeagnifolium and Sphaeralcea angustifolia. These forbs made up one quarter of the diet during the rainy season, a value lower to that reported in previous studies in the same area during the humid season (Mellado et al. 1991, 2003).

The concentration of nutrients in most forbs of Chihuahuan desert vegetation exceeds the nutritional requirements of ungulates (Nelson et al. 1970, SolteroGardea et al. 1994). The weight gain of kids is predominantly due to protein and water. Thus, apparently the feeding strategy of juvenile goats was to maximize the quality of the forage consumed, to choose tender-leaved forbs of high protein content.

During the dry season, when forbs were scarce, the goats' diet contained no more than $5 \%$ grasses, as has been reported previously in this region (Mellado et al. 1991, Lopez-Trujillo and García-Elizondo 1995).

The dissimilarity of diets between adult and juvenile goats during the rainy period is consistent with data of Richman and Johnson (1995). The difference in dietary selection between juvenile and adult goats could be related to the higher foraging skills of adult goats, because mature animals have longer reach, higher physical dexterity and strength, which can influence diet selection simply by providing access to desired species (Launchbaugh et al. 1999, Bugalho et al. 2001). The more experience the animal has with the forages available during several years, the greater its foraging abilities and probabilities to survive in a given environment (Senft et 
al. 1987, Senft 1989). In other studies with cattle, calves have also shown greater selectivity than older cattle (Ferrer Cazcarra and Petit 1995, Ferrer Cazcarra et al. 1995).

Most of the plant species had a high selection index, suggesting that goats in this environment foraged selectively. No attempt was made in this study to determine the factors affecting animal preference for forage plants, although it could be discussed that the higher preference for forbs by juvenile goats could be due to the higher protein content or lower levels of toxins of this group of tender forage. Ruminants seem to be able to select a diet that reflects their protein needs according to their physiological state (Kyriazakis and Oldham 1993, Cooper et al. 1994). In this study, adult goats had a higher preference for Agave lechuguilla (rainy season) and Prosopis glandulosa (dry season) than juvenile goats. These results suggest that certain unpalatable shrubs cause initial rejection early in life, but higher intakes of these forages are achieved later in life.

\section{Body Condition Score Effect}

Goats with low BCS showed a tendency toward a higher consumption of browse during the rainy season compared to goats with moderate BCS. However, some fibrous (e.g. Agave lechuguilla, Nolina cespitifera) or resinous (Flourensia cernua) species were used only by goats with low BCS, while goats with moderate BCS avoided them. On the other hand, goats with moderate BCS consumed greater amounts of tender-leaved highly nutritious shrubs such as Atriplex canescens and Buddleja scordioides, compared to goats with low BCS.

Given the higher proportion of shrub species, including a number of less preferred forages in the diet of goats with low BCS, it seems that the broader array of plants species utilized by these animals was an adaptive foraging strategy. The cost of consuming toxins from Flourensia cernua (Estell et al. 1998) and Agave lechuguilla (Francis et al. 2002) by goats with low BCS could be a trade-with the benefit of selecting a diet appropriate to the animal internal state.

Goats with moderate BCS rejected some fibrous and resinous forages. This is consistent with observations of Murden and Risenhoover (1993), who indicate that animals in a high nutritional state will often be more selective and choose diets different from animals in a poor nutritional state. During the rainy season, goats with moderate BCS also tended to consume

\section{Literature Cited}

low BCS. The greater proportion of forbs in the diet of goats with moderate BCS goats possibly resulted in greater nutrient ingestion, because in xeric environments, a positive relationship has been observed between dry matter digestibility and forbs and grasses content of goat diets (Sidahmed et al. 1981).

We do not ignore the possibility that heritable aspects of diet selection were expressed, because body condition score is moderately heritable in goats (Launchbaugh et al. 1999). Avoidance of Larrea tridentata shown by both groups of goats during the rainy season is consistent with other reports in the same type of vegetation (Mellado et al. 1991, 2003). Despite the high anti-quality factors of this shrub (Hyder et al. 2002), consumption of this plant by does when no suitable forage was available was much higher than levels previously reported (Mellado et al. 1991).

Similar to other studies in areas having wet and dry seasons (Lopez and Stuth 1984, Mellado et al. 1991, Genin and Pijoan 1993) consumption of dicotyledonous forages, mainly woody plants, markedly increased in the dry season in both goats with poor and moderate BCS, while grasses were rarely used.

\section{Conclusions}

The present study provides evidence that in a landscape of scarce grass and predominance of browse, in the rainy season, adult goats utilized more browse and less grass than juvenile does. Given that juvenile goats selected a greater proportion of monocots, less spine bearing-plants, and more forbs than adult goats, apparently the feeding strategy of juvenile goats was to explore their environment and maximize the quality of the forage consumed, choosing tender-leaved forbs of high nutrient content. These results are consistent with the contention that the feeding strategies of ruminant herbivores depend on their anatomical adaptations and body size, because their requirements for nutrients are proportional to their metabolic weight, so small (growing) animals require more nutrients per unit body weight. These results also support the idea that degree of fatness is related to grazing behavior in goats, because goats with low BCS selected more browse, including less preferred forages, thereby increasing the utilization of plant species normally rejected by herbivores in this type of vegetation.
Baptista, R. and K.L. Launchbaugh. 2001. Nutritive value and aversion of honey mesquite leaves to sheep. J. Range. Manage. 54:82-88.

Bugalho, M.N., J.A. Milne, and P.A. Racey. 2001. The foraging ecology of red deer (Cervus elaphus) in a Mediterranean environment: is a larger body size advantageous? J. Zool. 255:285-289.

Canfield, R.H. 1942. Application of the line interception method of sampling range vegetation. J. Forest. 39:388-394.

Cooper, S.D.B., I. Kyriazakis, and J.D. Oldham. 1994. The effect of late pregnancy on the diet selection made by ewes. Livest. Prod. Sci. 40:263-275.

DeRosa, G., V. Fedele, F. Napolitano, L. Gubitosi, A., Bordi, and R. Rubino. 1997. Dietary preferences in adult and juvenile goat. Anim. Sci. 65:457-463.

Du Toit, J.Y. 1990. Feeding-height stratification among African browsing ruminants. Afr. J. Ecol. 28:56-61.

Estell, R.E., E.L. Fredrickson, D.M. Anderson, K.M. Havstad, and M.D. Remmenga. 1998. Relationship of tarbush leaf surface terpene profile with livestock herbivory. J. Chem. Ecol. 24:1-12.

Ferrer Cazcarra, R.F. and M. Petit. 1995. The influence of animal age and sward height on the herbage intake and grazing behaviour of Charolais cattle. Anim. Sci. 61:497-506.

Ferrer Cazcarra, R.F., M. Petit, and P. D'hour. 1995. The effect of sward height on grazing behaviour and herbage intake of three sizes of Charolais cattle grazing cocksfoot (Dactylis glomerata) swards. Anim. Sci. 61:511-518.

Francis, G., Z. Kerem, H.P.S. Makkar, and K. Becker. 2002. The biological action of saponins in animal systems: a review. $\mathrm{Br}$. J. Nutr. 88:587-605.

Genin, D. and A.P. Pijoan. 1993. Seasonality of goat diet and plant acceptabilities in the coastal scrub of Baja California, Mexico. Small Rumin. Res. 10:1-11.

Grings, E.E., R.E. Short, M.R. Haferkamp, and R.K. Heitschmidt. 2001. Animal age and sex effects on diets of grazing cattle. J. Range Manage. 54:77-81.

Hobbs, N.T. and D.C. Bowden. 1982. Confidence interval on food preference indices. J. Wildl. Manage. 46:505-507.

Hyder, P.W., E.L. Fredrickson, R.E. Estell, M. Tellez, and R.P. Gibbens. 2002 . Distribution and concentration of total phenolics, condesed tannins, and nordihydroguaiaretic acid (NDGA) in creosotebush (Larrea tridentata). Bioch. Syst. Ecol. 30:905-912.

Illius, A.W. and I.J. Gordon. 1987. The allometry of food-intake in grazing ruminants. J. Anim. Ecol. 56:989-999.

Kyriazakis, I. and J.D. Oldham. 1993. Diet selection in sheep: the ability of growing lambs to select a diet that meets their crude protein requirements. Brit. J. Nutr. 69:617-629. 
Kyriazakis, I., B.J. Tolkamp, and G. Emmans. 1999. Diet selection and animal state: an integrative framework. Proc. Nutr. Soc. 58:765-772.

Launchbaugh, K.L., J.W. Walker, and C.A. Taylor. 1999. Foraging behavior: experience or inheritance? pp. 28-35. In: K.L. Launchbaugh, J.C. Mosley, and K.D. Sanders (eds) Grazing behavior of livestock and wildlife. Idaho Forest Wildl. Range Exp. Sta. Bull. 70 .

Lawrence, A.B. and D.G.M. Wood-Gush. 1998. Influence of social behaviour on utilization of supplemental feedblocks by Scottish hill sheep. Anim. Prod. 46:203-212.

Lopez, E.A. and J.W. Stuth. 1984. Dietary selection and nutrition of Spanish goats as influenced by brush management. J. Range Manage. 37:554-559.

Lopez-Trujillo, R. and R. García-Elizondo. 1995. Botanical composition and diet quality of goats grazing natural and grass reseeded shrublands. Small Rumin. Res. 16:37-47.

Mellado, M., R.H. Foote, A. Rodríguez, and P. Zarate. 1991. Botanical composition and nutrient content of diets selected by goats grazing on desert grassland in northern Mexico. Small Rumin. Res. 6:141-150.

Mellado, M., R. Valdez, L.M. Lara, and R. Lopez. 2003. Stocking rate effects on goats: A research observation. J. Range Manage. 56:167-173.

Murden, S.B. and K.L. Risenhoover. 1993. Effects of habitat enrichment on patterns of diet selection. Ecol. Appl.. 3:497-505.
Nelson, A.B., C.B. Herbel, and H.M. Jackson. 1970. Chemical composition of forage species selected by cattle on an arid New Mexico range. New Mexico Agr. Exp. Bull. 561.

Oosting, H.J. 1956. The study of plant communities. W.H. Freeman and Co. San Francisco, Calif.

Pfister, J.A., E.K. Panter, D.R. Gardner, B.L. Stegelmeier, M.H. Ralphs, R.J. Molyneux, and S.T. Lee. 2001. Alkaloids as anti-quality factors in plants on western U.S. rangeland. J. Range Manage. 54:447-461.

Pérez-Barbería, F.J. and I.J. Gordon. 1998. The influence of sexual dimorphism in body size and mouth morphology on diet selection and sexual segregation in cervids. Acta Vet. Hung. 46:357-367.

Ralphs, M.H. and F.D. Provenza. 1999. Conditioned food aversions: principles and practices, with special reference to social facilitation. Proc. Nutr. Soc. 58:813-820.

Ramirez, R.G., H. Gonzalez-Rodriguez, M.V. Gomez-Meza, and M.A. PerezRodriguez. 1999. Feed value of foliage from Acacia rigidula, Acacia berlandieri and Acacia farnesiana. J. Appl. Anim. Res. 16:23-32.

Richman, L.M. and D.E. Johnson. 1995. Diet selection by goats in the sagebrush steppe of eastern Oregon. Small Rumin. Res. 18:7-17.

Santucci, P.M. and O. Maestrini. 1985. Body conditions of dairy goats in extensive systems of production: method of estimation. Ann. Zootech. 34:473-474.
SAS. 1990. SAS procedure users guide version 6. Third edition. SAS Institute Inc., Cary, N.C.

Sidahmed, A.E., J.G. Morris, and S. Radosevich. 1981. Summer diet of Spanish goats grazing chaparral. J. Range Manage. 34:33-35

Senft, R.L. 1989. Hierarchical foraging models: Effects of stocking and landscape composition on simulated resource use by cattle. Ecol. Modeling 46:283-303.

Senft, R.L., M.B. Coughenour, D.W. Bailey, L.R. Rittenhouse, O.E. Sala, and D.W. Swift. 1987. Large herbivore foraging and ecological hierarchies. Biosc. 37:789-799.

Soltero-Gardea, S., I.M. Ortega, and F.C. Bryant. 1994. Nutrient content of important deer forage plants in the Texas coastal Bend. Texas J. Sci. 46:133-142.

Sparks, D.L. and J.C. Malechek. 1968. Estimating percentage dry weight in diets using a microscopic technique. J. Range Manage. 21:264-265.

Steel, R.G. and J.H. Torrie. 1980. Principles and procedures of statistics. Second Edition. McGraw-Hill Book Co., New York, N.Y.

Van Dyne, G.M. and H.F. Heady. 1965. Botanical composition of sheep and cattle diets on a mature annual range. Hilgardia $36: 465-468$. 